\title{
Mathematical modeling of the heat exchange in a stepped solar still
}

\author{
N. Samy ${ }^{1, *}$, A. A. El-sebaii ${ }^{1}$ S. Aboul-Enein ${ }^{1}$, M. R. I. Ramadan ${ }^{1}$, A.M. Khallaf ${ }^{2}$ \\ ${ }^{1}$ Department of Physics, Faculty of Science, Tanta University, Tanta, Egypt \\ ${ }^{2}$ Department of Basic Science, Misr Higher Institute for Engineering and Technology, Mansoura, Egypt \\ *Corresponding author E-mail: vet_alashkar@yahoo.com (N. Samy)
}

\begin{abstract}
A mathematical modeling for stepped solar still performance is carried out which is not found in most of the previous studies. Computer programs (using Pascal language) are developed for achieving this mathematical model. Effect of the parameters of the still configuration such as the still width $\left(b_{s}\right)$, depth of water $\left(d_{w}\right)$, tray width $(W)$ and the height of tray $(H)$ on the still's performance. Comparisons between the obtained theoretical results and the experimental results from other researches are carried out to corroborate the proposed mathematical model. Comparing thermal performance of the stepped solar still with that of the conventional one shows that the stepped solar still is more efficient. The daily productivity of the conventional and stepped solar stills are found to be 4.0 and $4.51\left(\mathrm{~kg} / \mathrm{m}^{2}\right.$ day); separately. The daily efficiency of the conventional and stepped solar stills are $61.48 \%$ and $78.33 \%$, individually.
\end{abstract}

Keywords: Stepped solar still. Heat transfer coefficient. Partial pressure. Efficiency. Productivity

\section{Introduction}

The needs of the fresh water are increased due to the populace development and quick industrialization. Desalination is one of the processes that recycled to change over brackish water into usable water which is appropriate for human utilization. Solar still is the awesome technique between the other desalination methods as it is the easiest and least expensive. There are several parameters that influence the performance of the solar still [1-4]. The still has the lowest performance with glass cover's inclination angles of $30^{\circ}-35^{\circ}$ and the best performance with angles of $20^{\circ}-25^{\circ}$ [5]. The yield of the still increases by $20 \%$ with $10 \mathrm{~mm}$ thickness of the black rubber and $19 \%$ with $20-30 \mathrm{~mm}$ thickness of black gravel [6]. With $0.033 \mathrm{~m}$ thickness of stearic acid at the basin liner, the productivity and efficiency of the still were obtained as $9.005 \mathrm{~kg} / \mathrm{m}^{2}$ day and $84.3 \%$, respectively [7, 8].

The stepped shape solar still was suggested for expanding the area of the basin liner by utilizing small trays $[9,10]$. An efficiency of $98 \%$ was accomplished in stepped shape solar still after finns and stones are utilized with the still [11]. The daily yield and efficiency of the still with five stepped tanks for heating and humidifying of agricultural greenhouse were obtained as $4.6-4.92 \mathrm{Kg} / \mathrm{m}^{2}$ day and $57-63 \%$, respectively $[12,13]$. Stepped solar still with sloping plates consisting of a group of shallow horizontal black trays has an efficiency up to 50\% [14]. A weir-type cascade stepped solar still combined with Paraffin wax as a phase change material (PCM) has been studied theoretically [15]. The yield of the modified still was improved by $125 \%$ [16]. About $30 \%$ increase in efficiency was achieved for the stepped solar still by utilizing pebbles and rocks as a sensible heat storage media [17]. The productivity of stepped double slope solar still by utilizing linen wicks $\left(\mathrm{LW}_{\mathrm{s}}\right)$ and carbon black nanoparticles $\left(\mathrm{CBN}_{\mathrm{s}}\right)$ was enhanced by about $80.57 \%$ with an efficiency of $110.5 \%$ [18]. Productivity with improving of $30.4 \%$ for the stepped solar still at tray water depth of $5 \mathrm{~mm}$ has been observed [19]. AbuJazar et al. [20] concluded that the yield and efficiency of the inclined copper stepped solar still are $4.383 \mathrm{~kg} / \mathrm{m}^{2}$ day and $58 \%$, respectively. An improving in the performance by $20 \%$ was observed for the photovoltaic thermal collector associating with a stepped solar still [21]. A novel design of a multi-side stepped square pyramid solar still (MSSPSS) was examined under passive and 
active forms [22]. The impact of joining stepped solar still with copper fins, transparent step walls and inner and outer reflectors was studied by Shmroukh et al. [23]. The output of the modified still increased by about $129 \%$ at basin water depth of $0.03 \mathrm{~m}$ and maximum efficiency of $63 \%$.

The main purpose for this study is carrying out a mathematical model for the stepped solar still using computer programing (Pascal language). Dimensions of the still are optimized for acquiring the ideal conditions for operating the still. Computations of various thermal performance parameters, for example, internal and external heat transfer coefficients, daily productivity and efficiency have been done. Investigating the Year-round performance of the stepped solar still has been carried out. Cost analysis of the stepped solar still is accomplished for predicting the optimum cost for the still.

\section{Mathematical Model}

A schematic diagram of the stepped solar still is shown in Fig.1.The stepped still as a similar construction of a conventional type. Furthermore, the absorber plate consists of several small steps with number of trays on horizontal side which offering minimum water depth. The evaporating surface of the still is assumed to have a zone of $1 \mathrm{~m}^{2}$. The solar intensity transferred over the glass cover and heat is moved to the water in the basin then the water temperature increments and it raises the amount of evaporation. The basin water transmissions heat to the inner surface of the glass cover through the heat transfer mechanisms. The heat is transmitted through the glass cover by conduction and afterward moves to the surrounding by convection to the ambient air and by radiation to the sky. Thermal resistance networks of the still elements are shown in Fig.2.

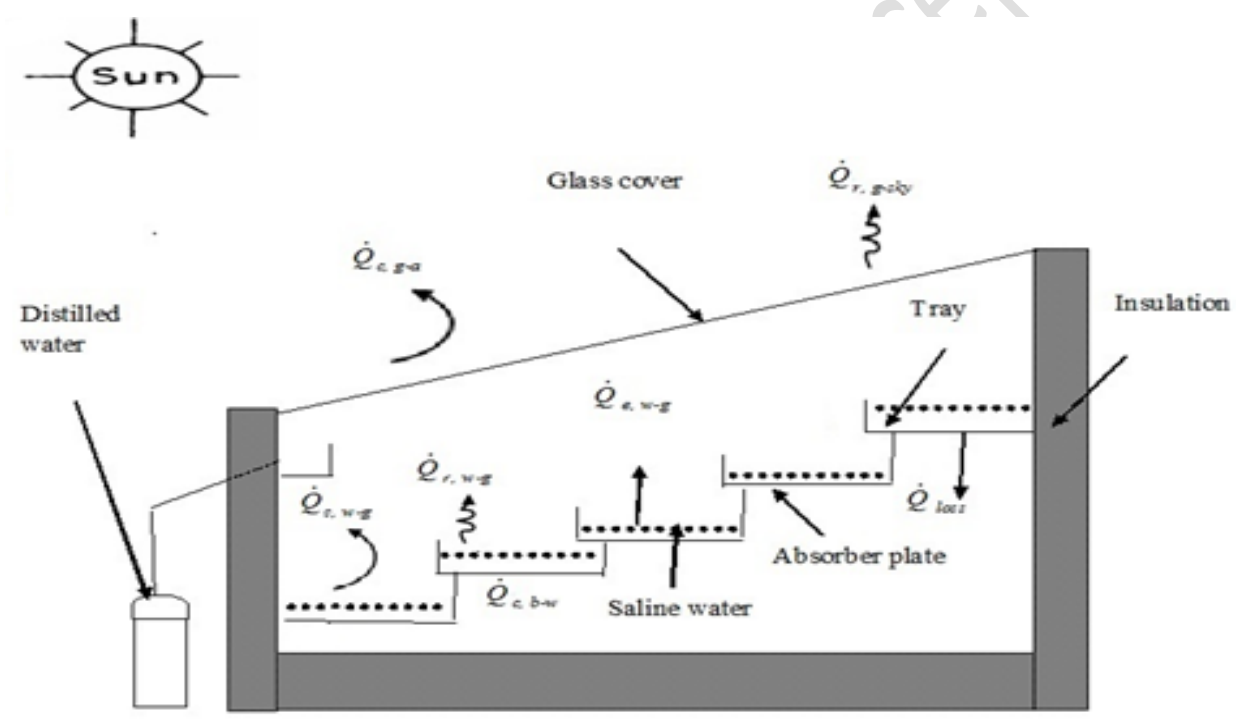

Figure 1. schematic diagram of the stepped solar still with heat transfer mechanisms.

For writing the energy balance equations for the several components of the still, the next expectations were taken into consideration:

1) The heat capacities of the glass cover, absorber plate are insignificant compared to that of the basin water.

2) The solar still is a vapor leakage proof.

3) By taking a small depth of the basin water, there is no temperature gradient across the water.

Due to the above expectations and with the help of the thermal resistances network, the energy balance equations for different features of the still are written as follows

\section{For the glass cover}

$$
I \alpha_{g} A_{g}+\dot{Q}_{c, w-g}+\dot{Q}_{r, w-g}+\dot{Q}_{e, w-g}=\dot{Q}_{r, g-s k y}+\dot{Q}_{c, g-a},
$$

\section{For the basin liner}


$I \tau_{g} \tau_{w} \alpha_{b} A_{b}+I_{v} \tau_{g} \tau_{w} \alpha_{b} A_{b}=\dot{Q}_{c, b-w}+\dot{Q}_{\text {loss }}$

For the basin water

$I \tau_{g} \alpha_{w} A_{w}+\dot{Q}_{c, b-w}=\dot{Q}_{c, w-g}+\dot{Q}_{r, w-g}+\dot{Q}_{e, w-g}+m_{w} C_{w}\left(\frac{d T_{w}}{d t}\right)$.

where $\dot{Q}_{c, b-w}$ is the rate of convective heat transfer between the basin liner and basin water and it is given by

$\dot{Q}_{c, b-w}=h_{c, b-w} A_{w}\left(T_{b}-T_{w}\right)$.

The convective heat transfer coefficient $\left(h_{c, b-w}\right)$ between the basin liner and water is obtained as[24]

$N u=0.54(G r . \operatorname{Pr})^{1 / 4}$.

$h_{c, b-w}=\frac{N u \cdot K_{w}}{X_{w}}=0.54\left(\frac{K_{w}}{X_{w}}\right)(G r . \operatorname{Pr})^{1 / 4}$.

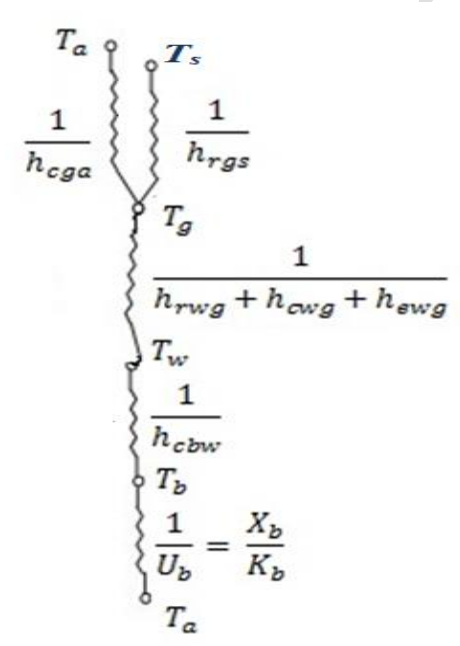

Figure 2. Thermal resistance network of the stepped solar still.

The convective $\left(\dot{Q}_{\mathrm{c}, \mathrm{w}-\mathrm{g}}\right)$, radiative $\left(\dot{Q}_{\mathrm{r}, \mathrm{w}-\mathrm{g}}\right)$ and evaporative $\left(\dot{Q}_{\mathrm{e}, \mathrm{w}-\mathrm{g}}\right)$ rates of heat transfer from the basin water to the glass cover. They are calculated using the following equations, respectively.

$\dot{Q}_{c, w-g}=h_{c, w-g} A_{g}\left(T_{w}-T_{g}\right)$,

$\dot{Q}_{r, w-g}=h_{r, w-g} A_{g}\left(T_{w}-T_{g}\right)$,

and

$\dot{Q}_{e, w-g}=h_{e, w-g} A_{g}\left(T_{w}-T_{g}\right)$.

The convective $\left(h_{c, w-g}\right)$, radiative $\left(h_{r, w-g}\right)$ and evaporative $\left(h_{e, w-g}\right)$ heat transfer coefficients between the basin water and glass cover are determined from the following Dunkle's correlations [24], respectively.

$h_{c, w-g}=0.884\left[\left(T_{w}-T_{g}\right)+\frac{\left(P_{w}-P_{g}\right) T_{w}}{\left(268900-P_{w}\right)}\right]^{1 / 3}$, 
$h_{r, w-g}=\varepsilon_{g} \sigma\left(T_{w}^{2}+T_{g}^{2}\right)\left(T_{w}+T_{g}\right)$,

and

$h_{e, w-g}=9.15 \times 10^{-7}\left[\frac{h_{c, w-g}\left(P_{w}-P_{g}\right) L_{w}}{\left(T_{w}-T_{g}\right)}\right]$.

where $P_{w}$ and $P_{g}$ are the partial vapor pressure at temperatures of the basin water and glass cover, respectively. They are calculated by the following expressions [25]

$P_{w}=\exp \left[25.317-\frac{5144}{\left(T_{w}+273\right)}\right]$,

and

$$
P_{g}=\exp \left[25.317-\frac{5144}{\left(T_{g}+273\right)}\right] \text {. }
$$

The radiative heat transfer between glass cover and sky $\dot{Q}_{r, g-s k y}$ is determined by

$\dot{Q}_{r, g-s k y}=h_{r, g-s k y} A_{g}\left(T_{g}-T_{s k y}\right)$.

where $h_{r, g-s k y}$ is the radiative heat transfer coefficient from the glass cover to sky. It is determined by the following equation [26]

$h_{r, g-s k y}=\varepsilon_{g} \sigma\left(T_{g}^{2}+T_{s k y}^{2}\right)\left(T_{g}+T_{s k y}\right)$.

The sky temperature is taken as [26]

$T_{s k y}=\left(T_{a}-6\right)$.

The convective heat transfer between the glass cover and the ambient air $\dot{Q}_{c, g-a}$ is determined by

$Q_{c, g-a}=h_{c, g-a} A_{g}\left(T_{g}-T_{a}\right)$.

The convective heat transfers co-efficient between glass cover and sky is given as [24]

$h_{c, g-a}=2.8+3.0 \mathrm{~V}$.

The back heat loss from the basin liner to ambient air is calculated from the following equation

$\dot{Q}_{\text {loss }}=U_{b} A_{b}\left(T_{b}-T_{a}\right)$.

Where $U_{b}=\left(K_{b} / X_{b}\right)$ is the bottom loss coefficient $\left(\mathrm{W} / \mathrm{m}^{2} \mathrm{~K}\right) . K_{b}$ and $X_{b}$ are the thermal conductivity and the thickness of the back insulation material, respectively.

From Eqs. (1) and (2) the values of temperatures of the glass cover $\left(T_{g}\right)$ and the basin liner $\left(T_{b}\right)$ can be determined as follows

$$
T_{g}=\frac{I \alpha_{g}+h_{1} T_{w}+h_{c, g-a} T_{a}+h_{r, g-s k y} T_{s k y}}{h_{1}+h_{c, g-a}+h_{r, g-s k y}},
$$

and

$T_{b}=\frac{I \tau_{g} \tau_{w} \alpha_{b} A_{b}+I_{v} \tau_{g} \tau_{w} \alpha_{b} A_{v}+h_{c, b-w} A_{b} T_{w}+U_{b} A_{b} T_{a}}{h_{c, b-w} A_{b}+U_{b} A_{b}}$.

Where $h_{1}=\left(h_{c, w-g}+h_{r, w-g}+h_{e, w-g}\right)$ is the total heat transfer coefficient between the basin water and the glass cover. On substituting $T_{g}$ and $T_{b}$, Eq. 3 can be simplified as $M \frac{d T_{w}}{d t}+a T_{w}=\overline{f(t)}$. 
Mathematical terms for $M, a$, and $\bar{f}(t)$ are given as

$$
\begin{aligned}
a= & h_{1} A_{w}+h_{c, b-w} A_{w}-\frac{h_{1}^{2} A_{w}}{h_{1}+h_{c, g-a}+h_{r, g-s k y}}-\frac{h_{c, b-w}^{2} A_{w}}{h_{c, b-w} A_{b}+U_{b} A_{b}} \\
M= & m_{w} C_{w}, \\
\overline{f(t)} & =I \tau_{g} \alpha_{w} A_{w}+\frac{I h_{1} \alpha_{g} A_{w}}{h_{1}+h_{c, g-a}+h_{r, g-s k y}}+\frac{h_{1} h_{r, g-s k y} A_{w} T_{s k y}}{h_{1}+h_{c, g-a}+h_{r, g-s k y}}+ \\
& +\left[\frac{h_{1} h_{c, g-a} A_{w}}{h_{1}+h_{c, g-a}+h_{r, g-s k y}}+\frac{U_{b} h_{c, b-w} A_{b} A_{w}}{h_{c, b-w} A_{b}+U_{b} A_{b}}\right] T_{a}+\frac{I \tau_{g} \tau_{w} \alpha_{w} h_{c, b-w} A_{b} A_{w}}{h_{c, b-w} A_{b}+U_{b} A_{b}}+ \\
& +\frac{I_{v} \tau_{g} \tau_{w} \alpha_{w} h_{c, b-w} A_{w} A_{v}}{h_{c, b-w} A_{b}+U_{b} A_{b}} .
\end{aligned}
$$

The method of separation of variables has been used for solving Eq. 23 using the primary condition $T w$ $(t=0)=T w i$ ( $T w i$ is the primary temperature of the basin water). The solution of Eq. 23 is obtained as

$T_{w}=\frac{\overline{f(t)}}{a}[1-\exp (-a t / M)]+T_{w i} \exp (-a t / M)$.

The hourly productivity $P_{h}$ is determined as

$$
P_{h}=\frac{h_{e, w-g}\left(T_{w}-T_{g}\right) \times 3600}{L_{w}} \text {. }
$$

Where $L_{w}$ is the latent heat of vaporization of water $(\mathrm{J} / \mathrm{kg})$. It is calculated using the following nonlinear correlation [27]

$$
L_{w}=3044205-1670.1109 T_{w}-1.14258 T_{w}^{2} \text {. }
$$

The daily productivity $\left(P_{d}\right)$ and efficiency $\left(\eta_{d}\right)$ are determined by the following equations, respectively [24].

$$
P_{d}=\sum_{24 h} P_{h}
$$

and

$$
\eta_{d}=\frac{P_{d} L_{w, a v e}}{A_{b}\left(\sum I\right) \Delta t} .
$$

Climatic, design and operational conditions are the three parameters are utilized as the input parameters for the mathematical modeling. Climatic conditions are surrounding air temperature, speed of the wind, and solar intensity for Tanta (Lat. 30 $47^{\backslash} \mathrm{N}$ ) throughout the year of 2015. Design parameters are the values of the dimensions used for constructing the stepped solar still. Operational parameters such as the depth of the still's water. Temperatures of different parts of the still equal the ambient temperature at time $t=0$; after a time $\Delta t$, these temperatures are determined utilizing the different heat transfer coefficients and the values of various climatic conditions. The values of the significant parameters utilized in mathematical calculations are recorded in Table (1). Computer program (by Pascal language) has been used for predicting the values of solar radiation incident on tray's vertical surface utilizing that measured on a horizontal surface. The hourly productivity $\left(P_{h}\right)$ can be determined for a similar time $\Delta$ t. Also, the daily productivity $\left(P_{d}\right)$ and efficiency $\left(\eta_{d}\right)$ are calculated for the still. 
Table 1. Important factors used in mathematical calculations $[24,26]$.

\begin{tabular}{cclc}
\hline $\begin{array}{c}\text { Relevant } \\
\text { parameter }\end{array}$ & Value & Relevant parameter & Value \\
\hline$\alpha_{g}$ & 0.05 & $K_{s}=K_{b}$ & $0.059(\mathrm{~W} / \mathrm{m} \mathrm{k})$ \\
$\tau_{g}$ & 0.9 & $\alpha_{b}$ & 0.90 \\
$\varepsilon_{g}$ & 0.85 & $K_{w}$ & $0.6405(\mathrm{~W} / \mathrm{m} \mathrm{k})$ \\
$\alpha_{w}$ & 0.05 & $\rho_{w}$ & $1000\left(\mathrm{~kg} / \mathrm{m}^{3}\right)$ \\
$\tau_{w}$ & 0.95 & $C_{w}$ & $4190(\mathrm{~J} / \mathrm{kg} \mathrm{k})$ \\
$\varepsilon_{w}$ & 0.96 & $\sigma$ & $5.669 \times 10^{8}\left(\mathrm{~W} / \mathrm{m}^{2} \mathrm{k}^{4}\right)$ \\
$\mathrm{G}$ & $9.8 \mathrm{~m} / \mathrm{s}^{2}$ & & \\
\hline
\end{tabular}

\section{Results and discussion}

A theoretical study on thermal performance of the stepped solar still has been performed. Hourly Variations of the determined temperatures of various components of the still viz; basin liner $\left(T_{b}\right)$, the basin water $\left(T_{w}\right)$ and glass cover $\left(T_{g}\right)$ are presented in Fig. 3. Values of the solar radiation $(I)$ and temperature of the ambient air $\left(T_{a}\right)$ are incorporated also in this figure. From the figure, all temperatures and solar radiation rise with time until they reach their extreme values and after that they start to reduce. The greatest values of $T_{b}, T_{w}$ and $T_{g}$ are found to be $45.81,43.42$ and $36.45{ }^{\circ} \mathrm{C}$, respectively. Figures 4 and 5 summarize the hourly variations of the temperature $\left(T_{w}\right)$ and maximum temperature $\left(T_{w, \max }\right)$ of basin water with different values of width of the still $\left(b_{s}\right)$ that varies from 0.11 to $1 \mathrm{~m} . T_{w}$ and $T_{w, \max }$ increase with increasing $b_{s}$ because of the growth in the still exposure area to solar radiation, this lead to increase the amount of water vapor condensation on the interior surface of the glass cover.

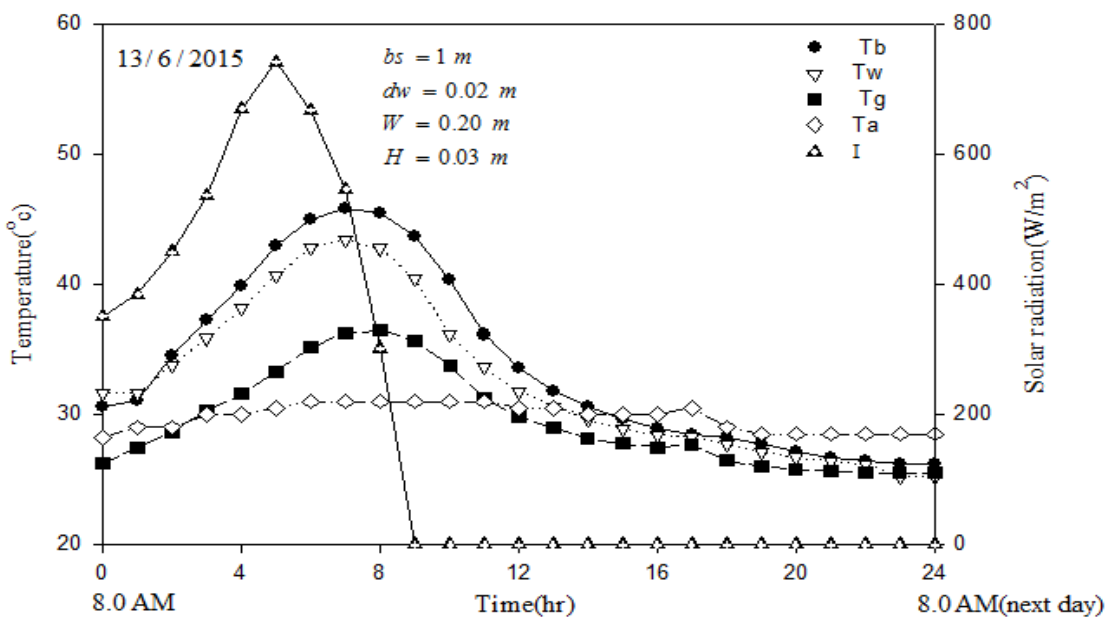

Figure 3. Hourly variations of the calculated temperatures of different components of the still, Ambient air temperature and solar intensity are shown also. 


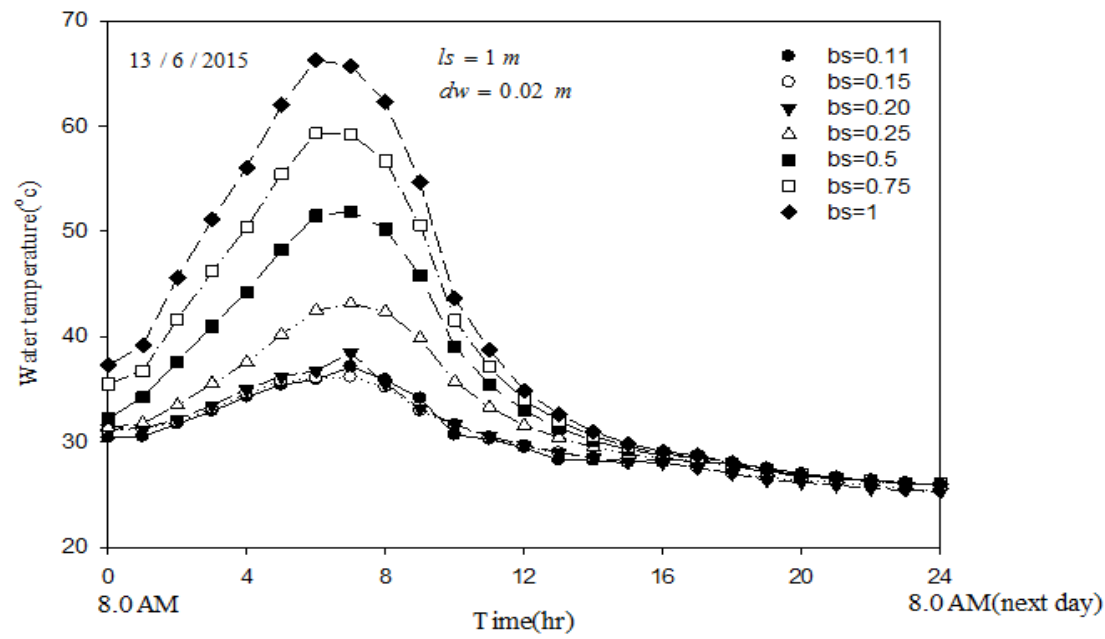

Figure 4. Hourly variations of the water temperature $\left(T_{w}\right)$ for different values of the still width $\left(b_{s}\right)$.

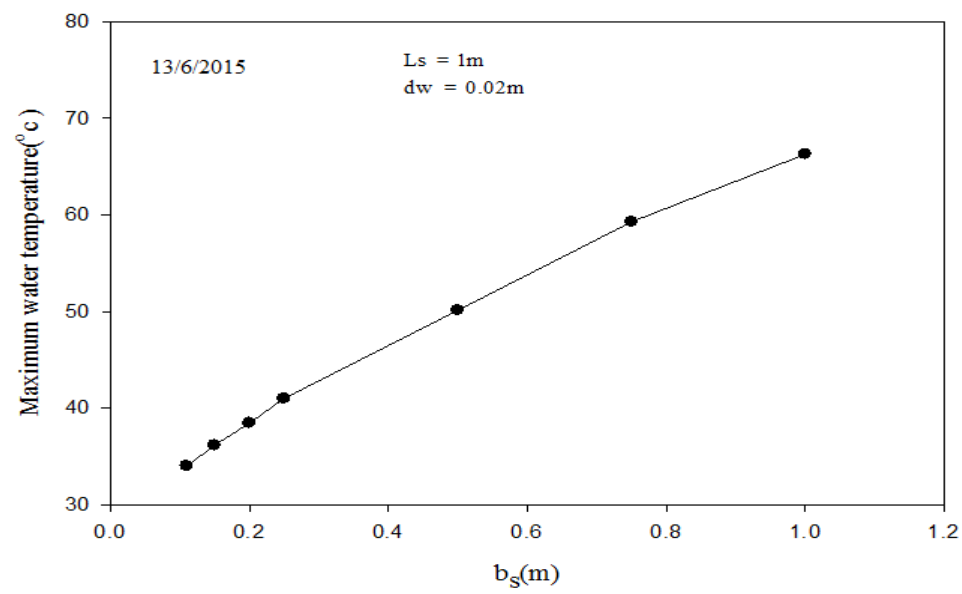

Figure 5. Variations of the maximum water temperatures $\left(T_{w, \max }\right)$ with different values of the still width $\left(b_{s}\right)$.

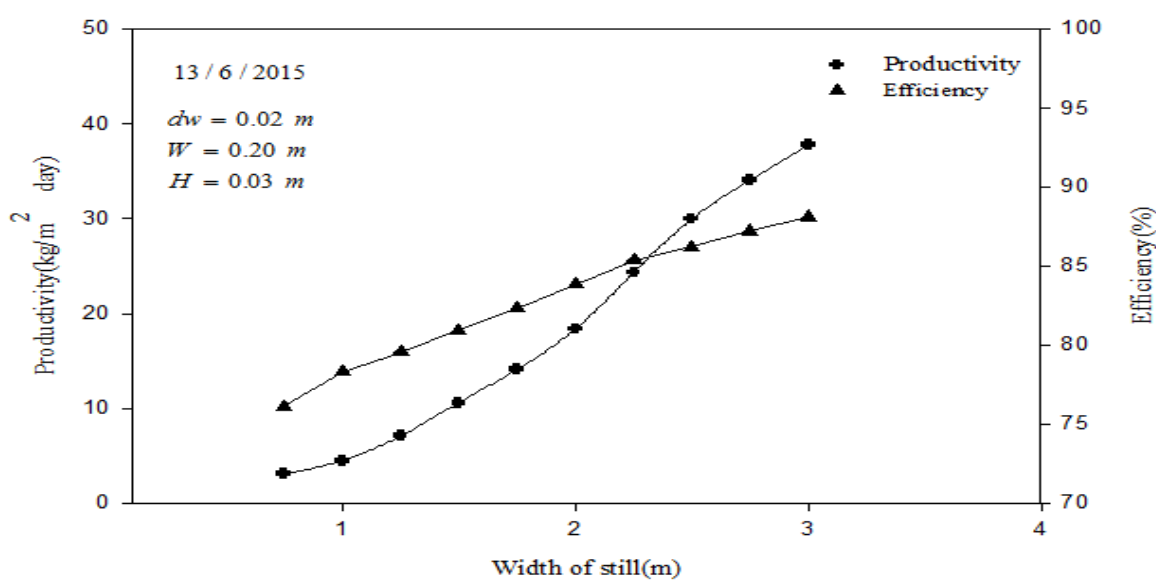

Figure 6. Variations of daily productivity and efficiency with different values of width of still(bs).

The values of $T_{w, \max }$ are found to vary from 37.12 to $64.23{ }^{\circ} \mathrm{C}$ with values of $b_{s}$ vary from 0.11 to $1 \mathrm{~m}$. Figs. $(6,9,12,15)$ illustrate the relation between the parameters that affecting the yield of stepped solar 
still like width of still, water depth, width of tray and height of still with productivity \& efficiency. The optimum value of both productivity and efficiency are revealed to be $4.51 \mathrm{~kg} / \mathrm{m}^{2}$ day and $78.33 \%$, individually.

Influence of varying the depth of basin water $\left(d_{w}\right)$ on temperature $\left(T_{w}\right)$ and maximum temperature $\left(T_{w, \text { max. }}\right)$ of basin water is introduced in Figs. 7 and 8, respectively. During the daylight time, $T_{w}$ and $T_{w, \max }$ decrease with increasing $d_{w}$ because of the increasing heat capacity of basin water. After sunset, they increase significantly with the increase of $d_{w}$ because of the increase of the heat stored in water. These results approve with those got by Alaudeen et al. [28]. Figures 10 and 11 show the variations of the temperature $\left(T_{w}\right)$ and maximum temperature $\left(T_{w, \text { max. }}\right)$ of basin water with different values of width $(W)$ and height $(H)$ (Figs. 13, 14) of the tray. $T_{w}$ and $T_{w, \max }$ increase with increasing of $\mathrm{W}$ and $H$ due to the increased amount of the absorbed solar radiation. The values of $T_{w, \max }$. are found to vary from 42.41 to $56.65{ }^{\circ} \mathrm{C}$ with values of $W$ between 0.02 and $0.20 \mathrm{~m}$. The corresponding values of $T_{w, \max }$ vary from 43.42 to $66.44^{\circ} \mathrm{C}$ with values of $H$ vary from 0.01 and $0.10 \mathrm{~m}$.

To validate the proposed theoretical model, utilizing a similar climatic, design and operational conditions, comparisons between the calculated results acquired from the current study and the experimental outcomes revealed by previous work [21, 29 and 30] are carried out. Figures 16-18 introduced the hourly variation of the calculated and measured values of the temperatures of the glass cover $\left(T_{g}\right)$ and basin water $\left(T_{w}\right)$. From the three figures, there is a good agreement between these two results. The relative percentage differences between the obtained results and those concluded by Abdullah et al. [21] are found to be 0.061 and 0.062 for $T_{g}$ and $T_{w}$, respectively. The corresponding results for the results obtained by Muftah et al. [29] and Omara et al. [30] are gotten as 0.009 and 0.060 for $T_{g}$ and 0.058 and 0.062 for $\mathrm{T}_{\mathrm{w}}$, separately. Comparisons between the calculated and measured values of the hourly

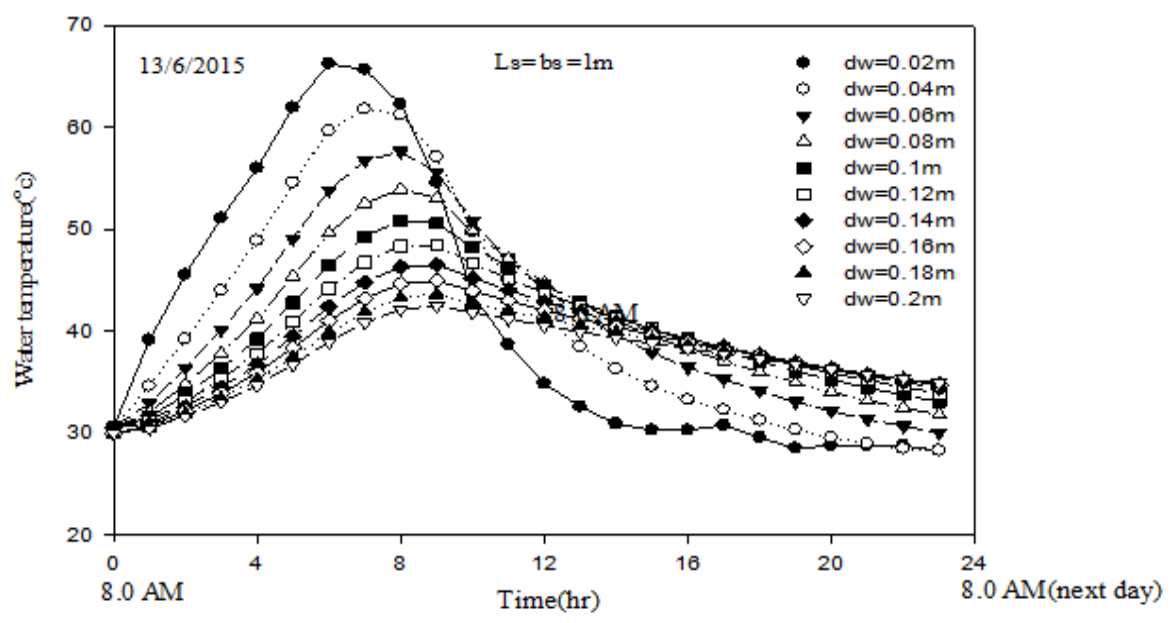

Figure 7. Variations of the water temperature $\left(T_{w}\right)$ for different values of depth of the basin water $\left(d_{w}\right)$. 


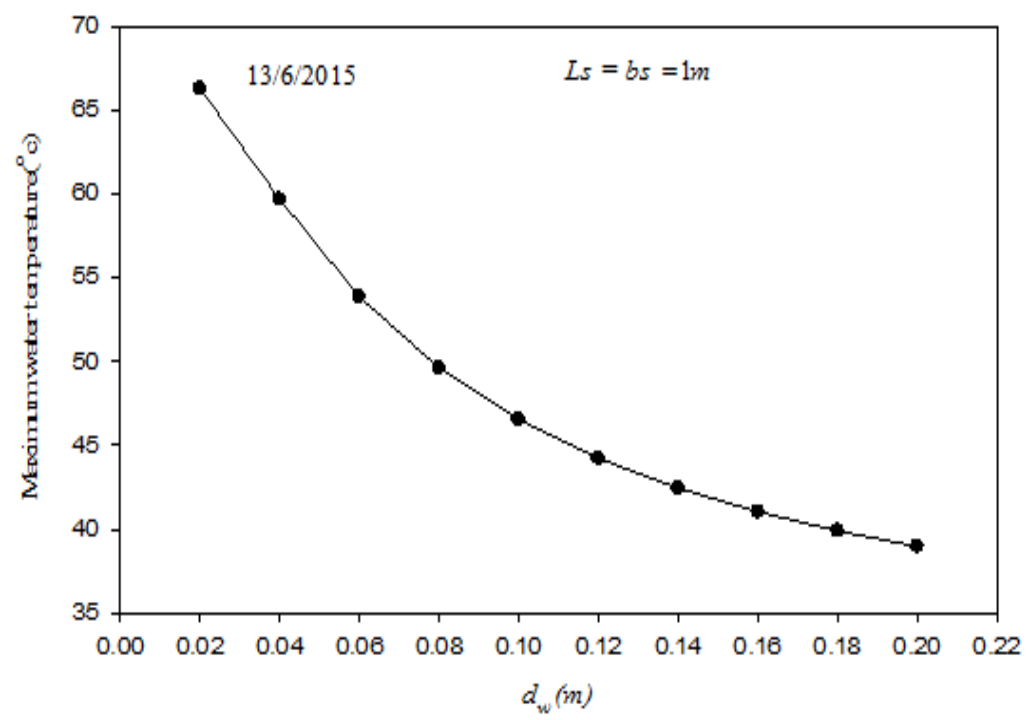

Figure 8. Variations of the maximum water temperature $\left(T_{w, \max }\right)$ for different values of depth of the basin water $\left(d_{w}\right)$.

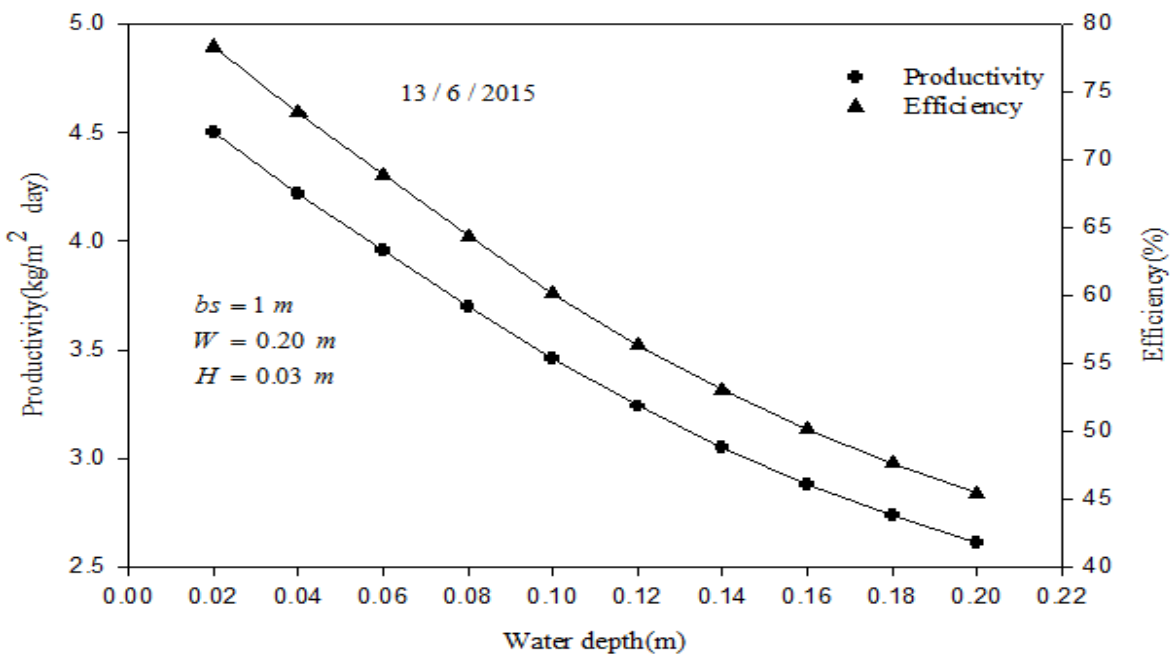

Figure 9. Variations of daily productivity and efficiency with different values of water depth(dw).

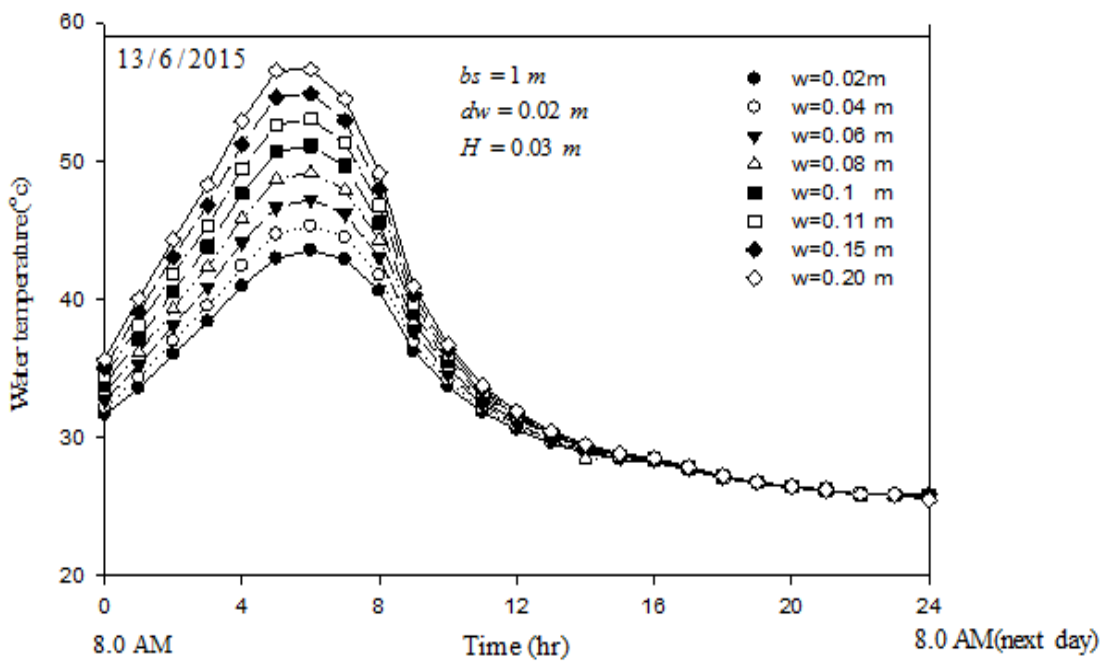


Figure 10. Variations of the water temperature $\left(T_{w}\right)$ for different values of the width of the tray $(W)$.

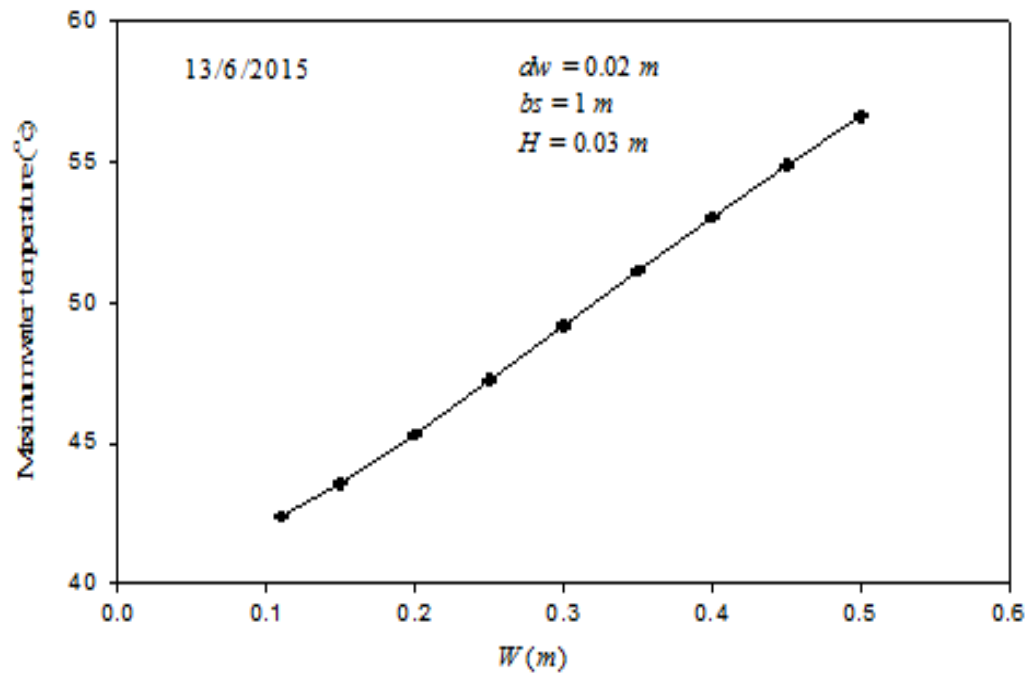

Figure 11. Maximum water temperature $\left(T_{w, \max }\right)$ for different values of the width of the tray $(W)$.

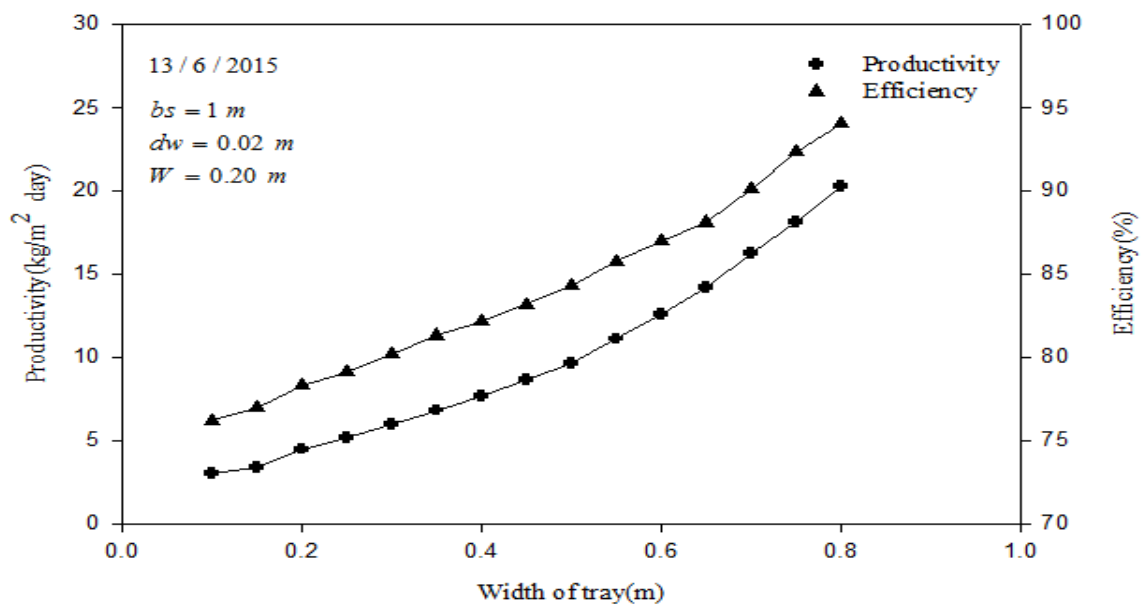

Figure 12. Variations of daily productivity and efficiency with different values of width of tray(W).

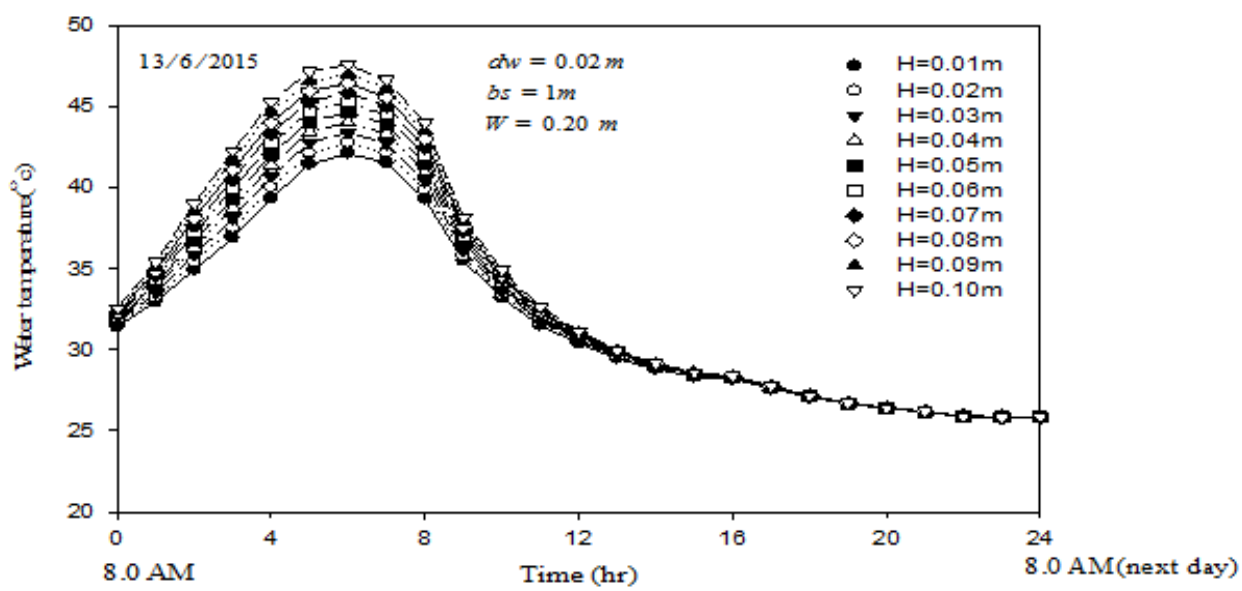


Figure 13. Hourly variations of the water temperature $\left(T_{w}\right)$ for different values of the height of the $\operatorname{tray}(H)$.

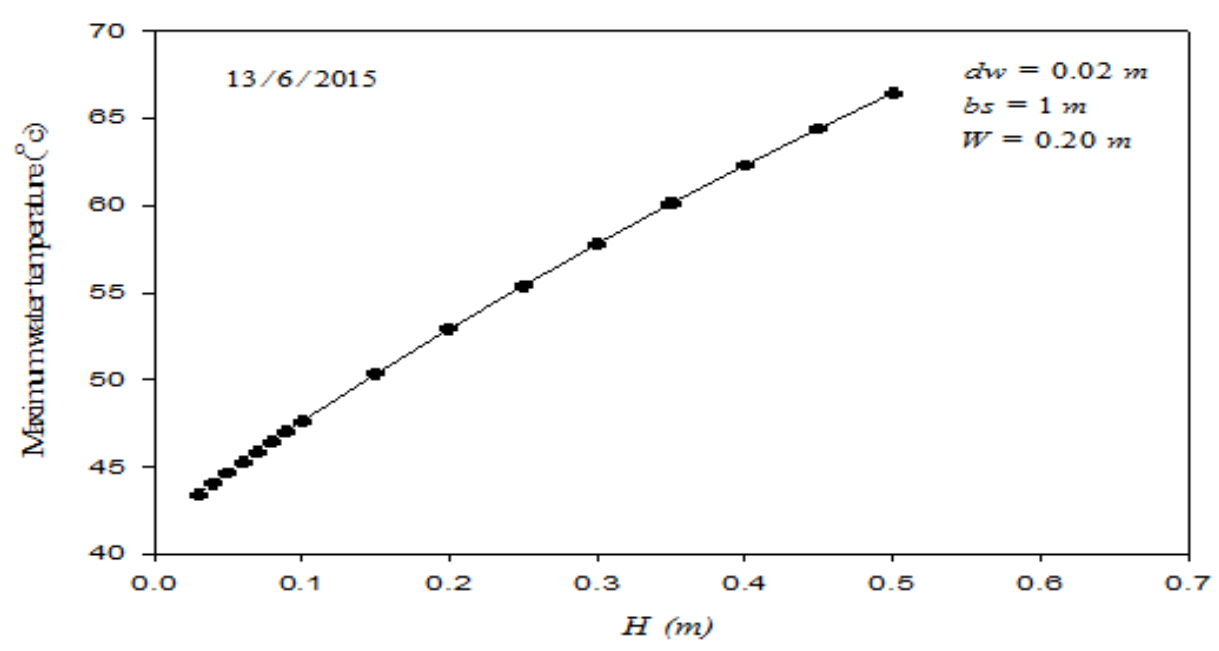

Figure 14. Maximum water temperature $\left(T_{w, \max }\right)$ for different values of the height of the tray $(H)$.

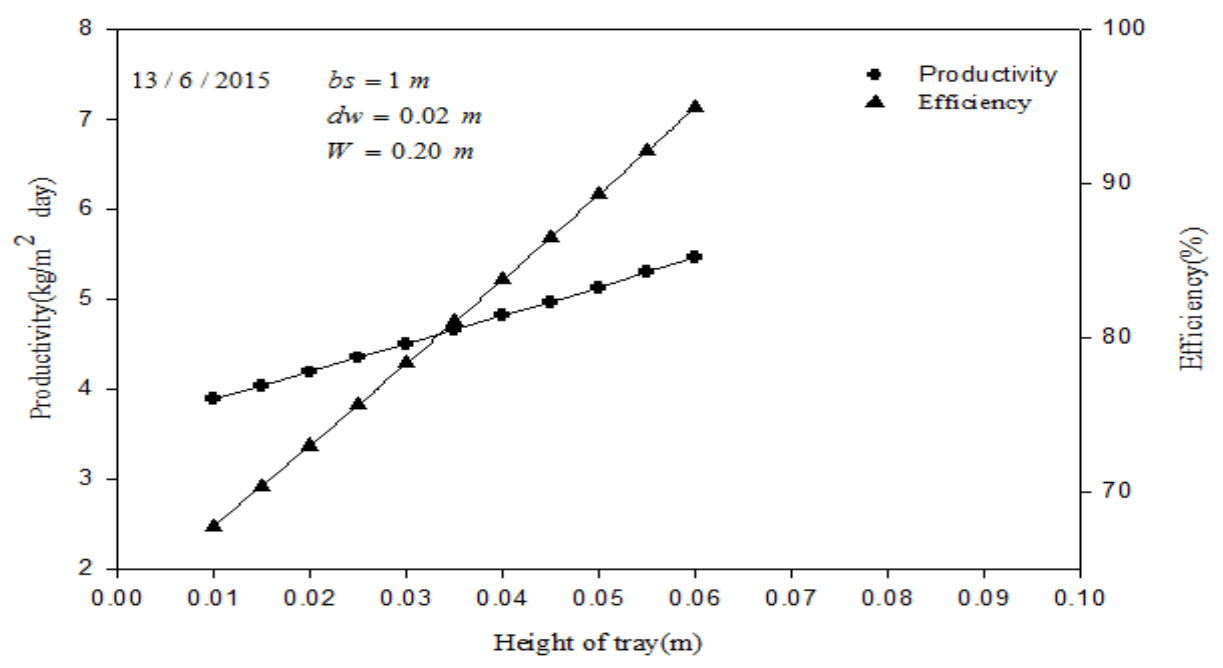

Figure 15. Variations of daily productivity and efficiency with different values of height of tray $(\mathrm{H})$. 


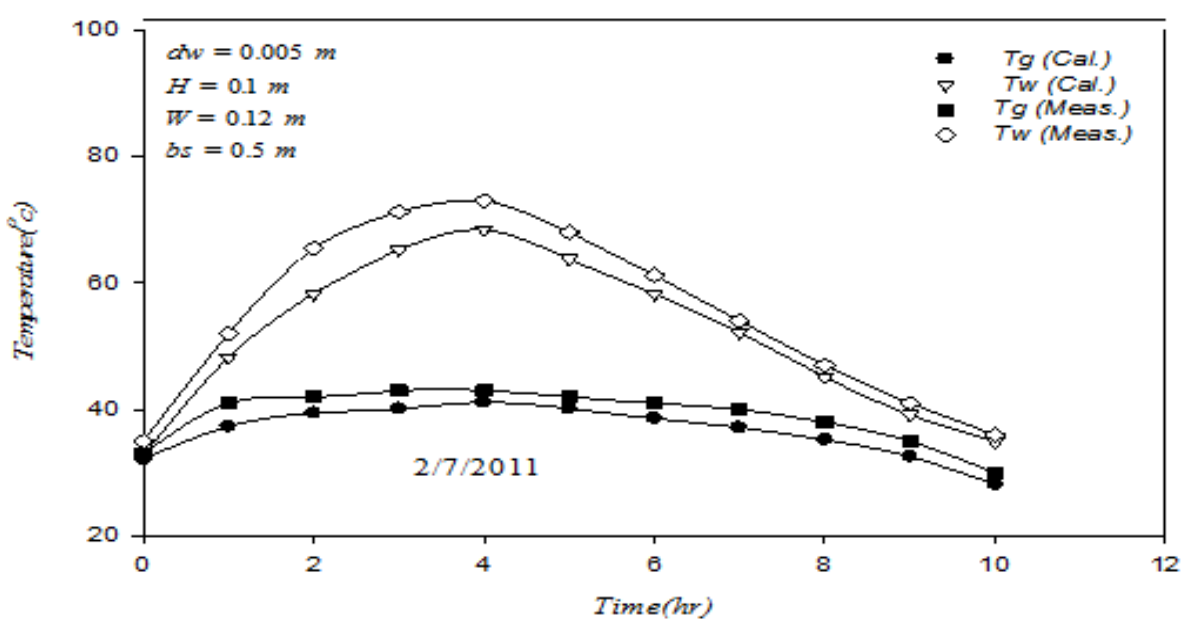

Figure 16. Calculated and measured [21] values of the temperature of the glass cover $\left(T_{g}\right)$ and basin water $\left(T_{w}\right)$.

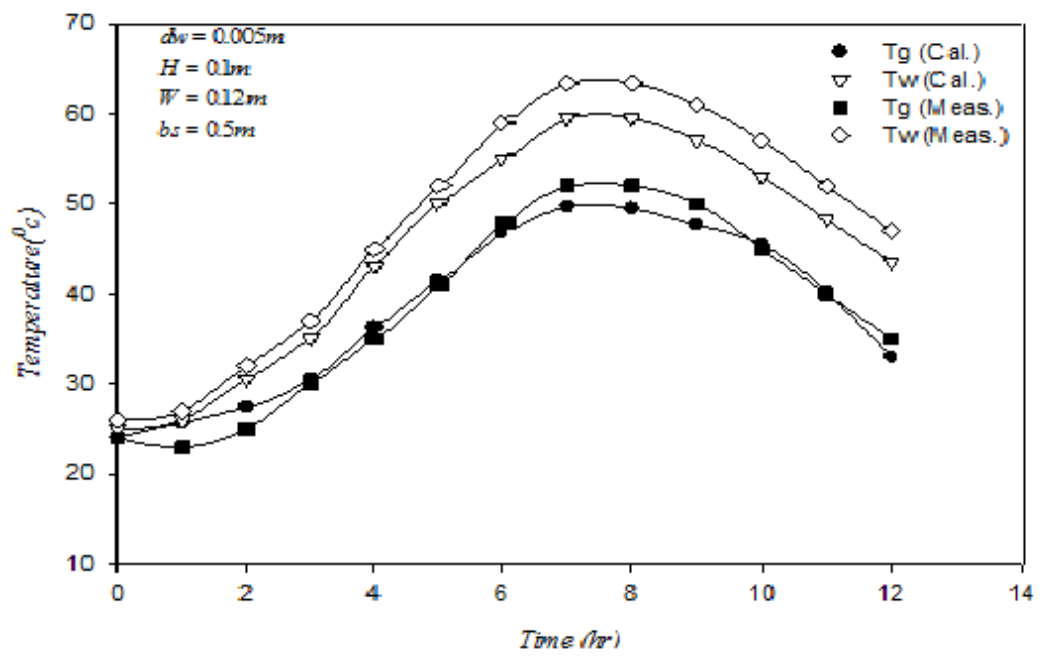

Figure 17. Calculated and measured [29] values of the temperature of the glass cover $\left(T_{g}\right)$ and basin water $\left(T_{w}\right)$.

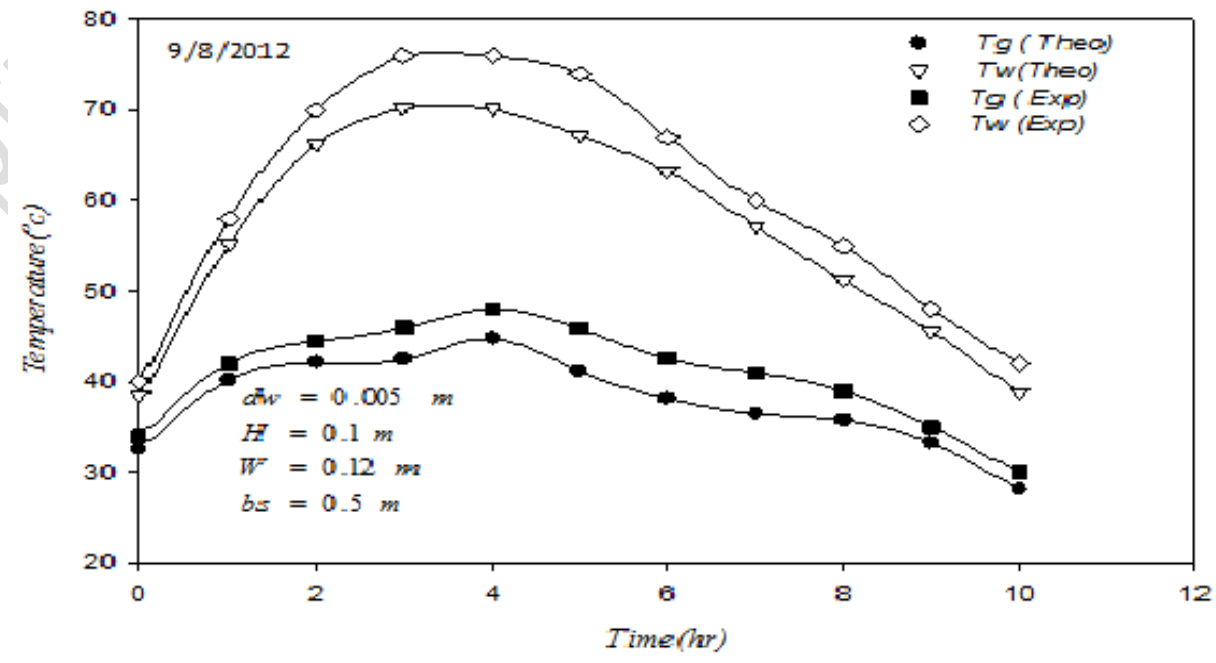

Figure 18. Calculated and measured [30] values of the temperature of the glass cover $\left(T_{g}\right)$ and basin water $\left(T_{w}\right)$. 
productivity $\left(P_{h}\right)$ are presented in Figs. 19-21. Good agreement between the two outcomes (calculated and measured) is observed. The relative percentage differences between the obtained results and those concluded by Abdullah et al. [21], Muftah et al. [29] and Omara et al. [30] are obtained as 0.140, 0.032 and 0.120 , respectively. The previous results verify that the proposed mathematical model can be used for expecting thermal performance of the stepped solar still with a reasonable accuracy.

Hourly productivity $\left(P_{h}\right)$ of the conventional and stepped solar stills is shown in Fig.22. The productivity $\left(P_{h}\right)$ for the stepped solar still is higher than that of the conventional one by about $15 \%$. The daily productivity $\left(P_{d}\right)$ for the conventional and stepped solar stills are found to be 4.0 and 4.15 $\mathrm{kg} / \mathrm{m}^{2}$ day, individually. Figure 23 presents the hourly values of the convective $\left(h_{c, w-g}\right)$ and evaporative $\left(h_{e, w-g}\right)$ heat transfer coefficients of the stepped solar still. It can be seen that $h_{c, w-g}$ is less depending on temperature. On the other hand, $h_{e, w-g}$ increases until achieving the maximum value of $30.26 \mathrm{~W} / \mathrm{m}^{2} \mathrm{~K}$, then it decreases with time.

Using the proposed model, year-round thermal performance of the stepped solar still can be performed. Figure 24. Summarizes the values of the daily productivity $\left(P_{d}\right)$ and efficiency $\left(\eta_{d}\right)$ through the months of the year 2015. It is clear from this figure that; for the stepped solar still, $P_{d}$ has a minimum value of $3.29 \mathrm{~kg} / \mathrm{m}^{2}$ day in December and a maximum value of $7.03 \mathrm{~kg} / \mathrm{m}^{2}$ da y in July. Also, the monthly average of daily efficiency $\left(\eta_{d}\right)$ varies from $49.82 \%$ in December and a maximum value of $67.23 \%$ in July.

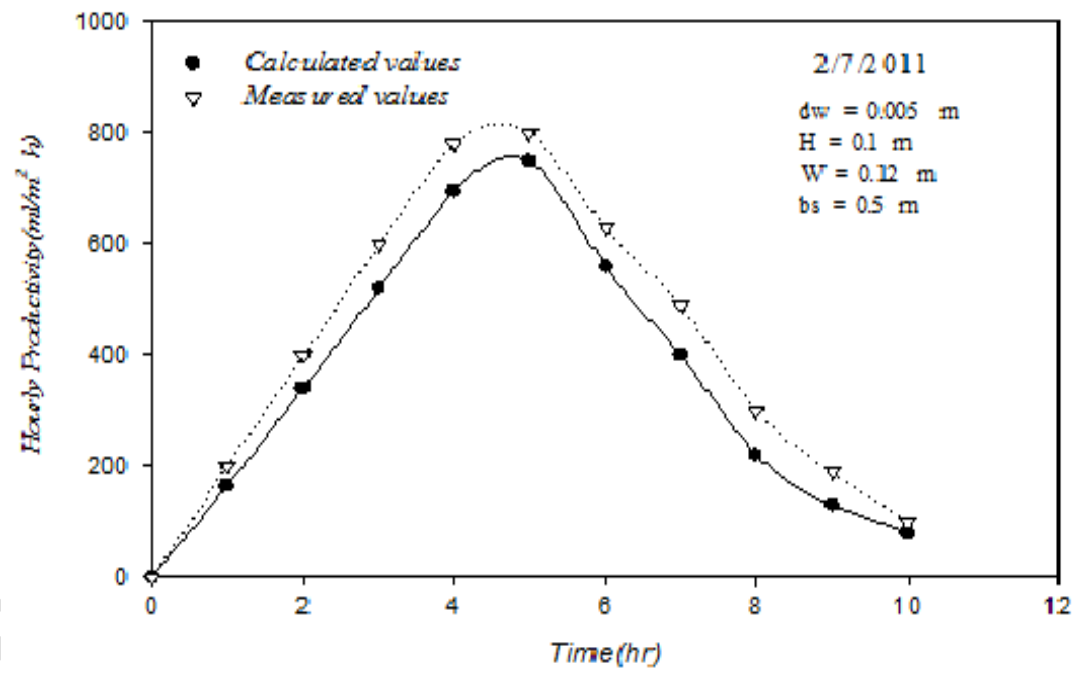

Figure 19. Hourly variations of the calculated and measured [21] values of the hourly productivity $\left(P_{h}\right)$. 


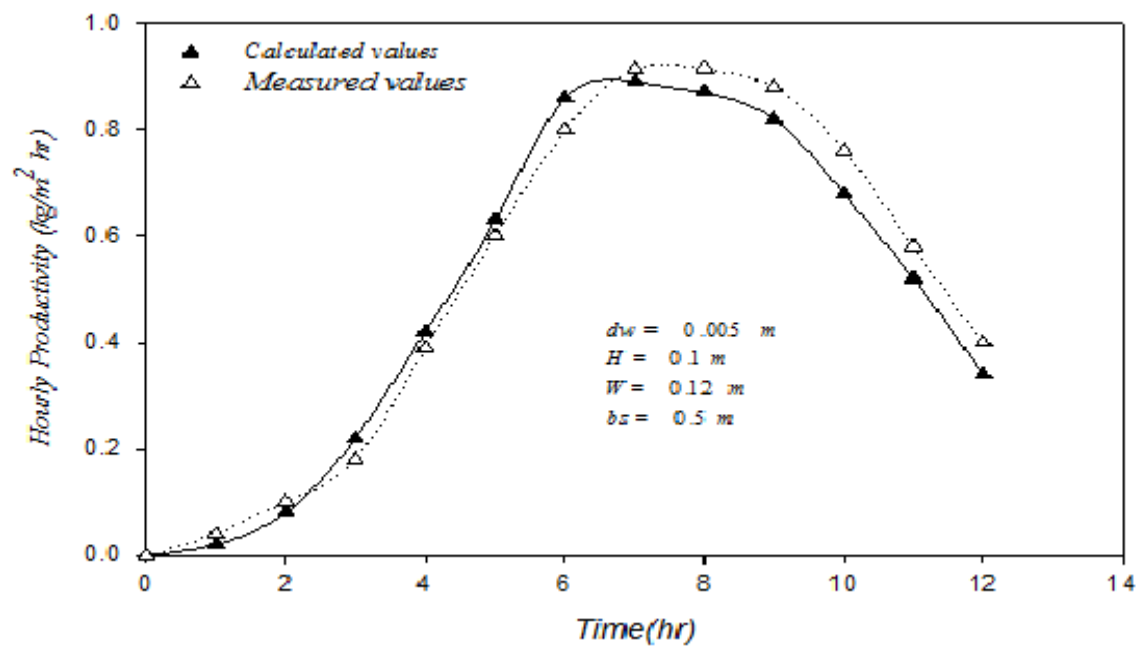

Figure 20. Hourly variations of the calculated and measured [29] values of the hourly productivity $\left(P_{h}\right)$.

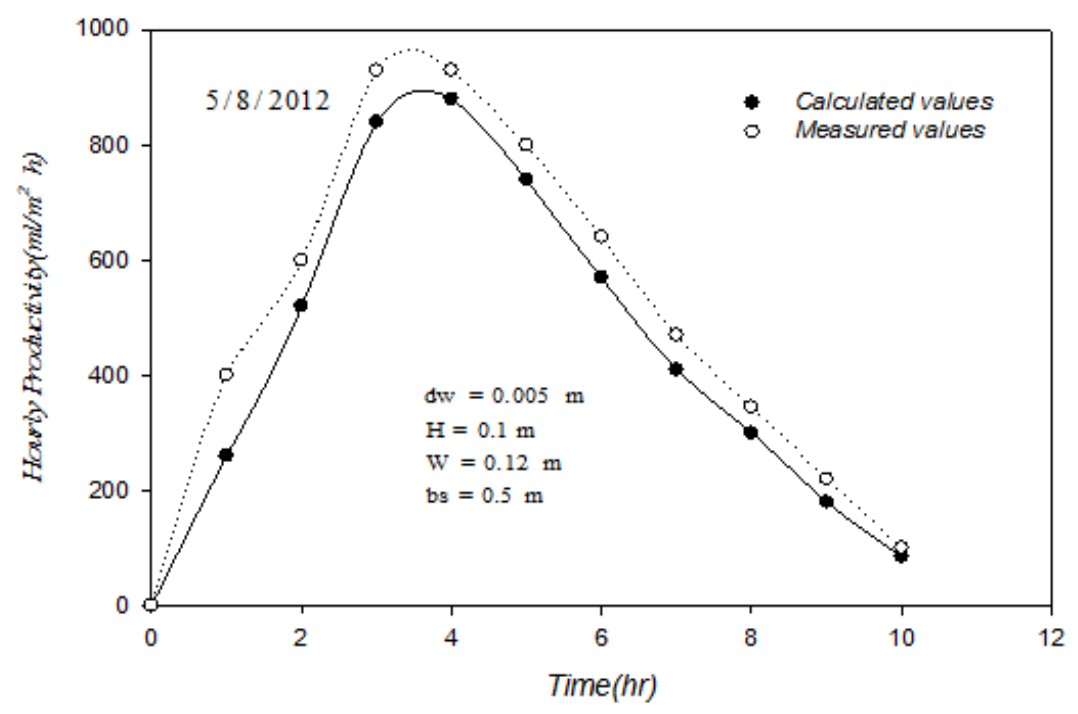

Figure 21. Hourly variations of the calculated and measured [30] values of the hourly productivity $\left(P_{h}\right)$. 


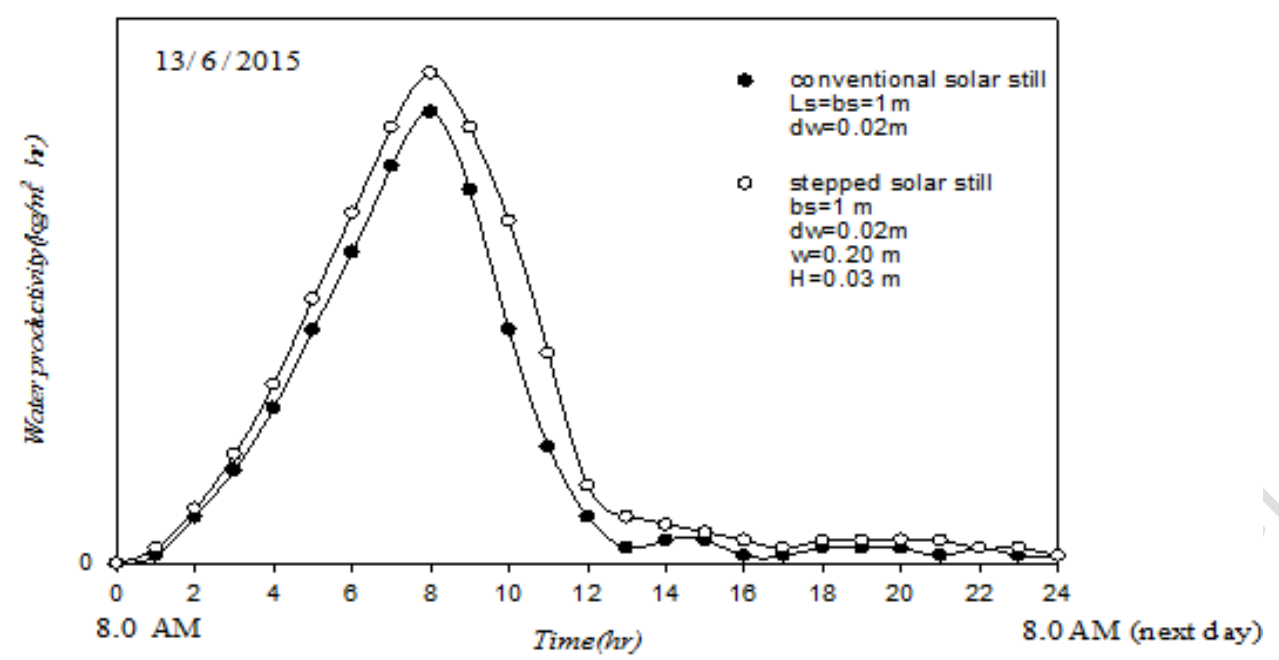

Figure 22. Variations of the hourly productivity $\left(P_{h}\right)$ for the stepped and conventional solar stills.

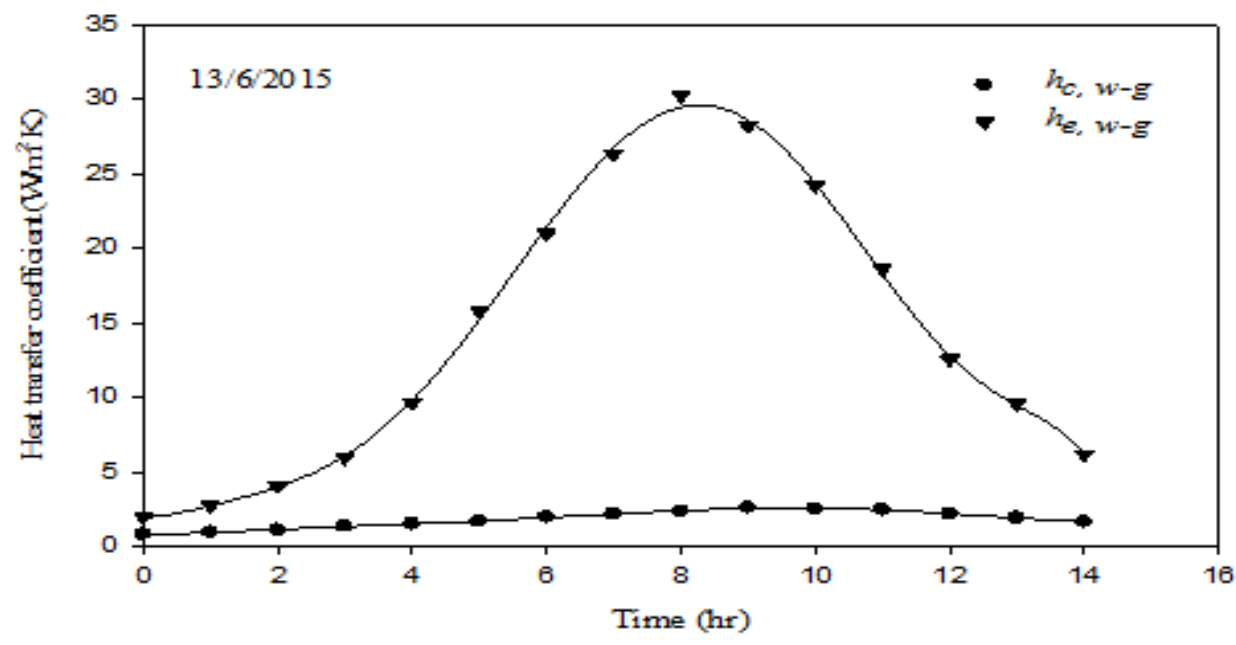

Figure 23. Variations of the convective $\left(h_{c, w-g}\right)$ and evaporative $\left(h_{e, w-g}\right)$ heat transfer coefficients for the stepped solar still.

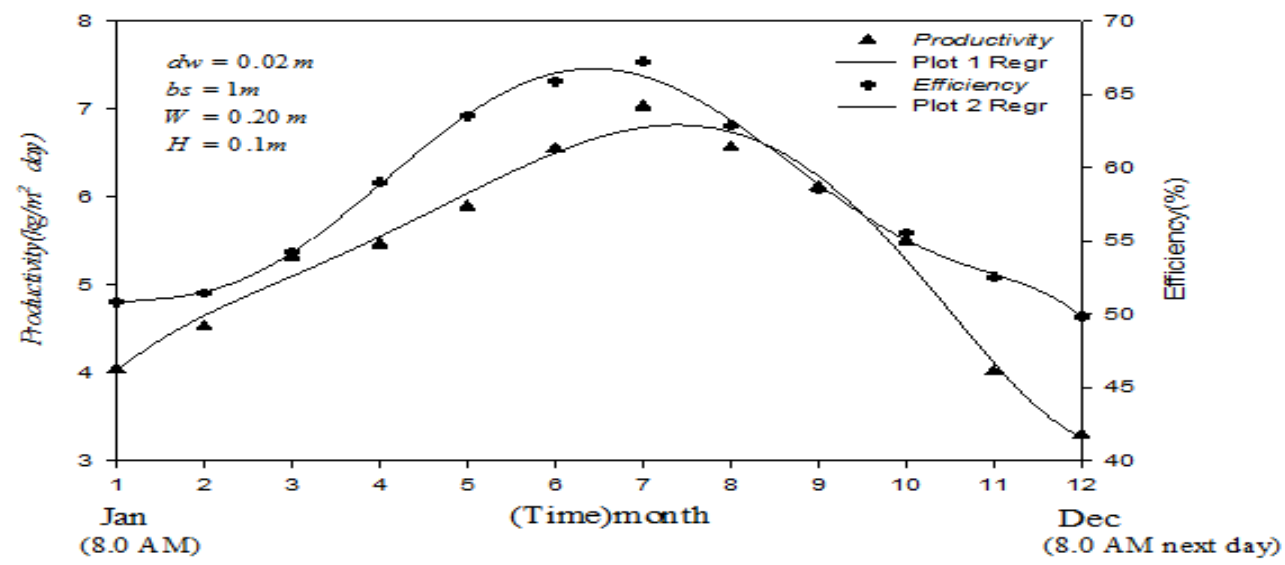

Figure 24. Monthly average values of daily productivity $\left(P_{d}\right)$ and efficiency $\left(\eta_{d}\right)$ for the stepped solar still during the year 2015 . 


\section{Cost analysis}

The cost analysis of the stepped and conventional solar stills has been done. Table 2 reviews the details of the expense investigation for the two systems which shows that the stepped solar still cost is lower than the conventional solar still.

Table 2. Cost analysis in (LE) of the solar stills (LE=US \$0.06) [31].

\begin{tabular}{llc}
\hline Still component & Stepped Solar Still & Conventional Solar Still \\
\hline Absorber plate (cooper sheet 1 mm) & 1125 & $\mathbf{8 7 5}$ \\
Glass cover 1mm & 187.5 & 187.5 \\
Galvanized iron 1mm thick & 750 & 750 \\
(from inside \& outside of the still) & & \\
Insulation (foam 5 cm thick) & 187.5 & 187.5 \\
Internal coating by Epoxy 165 & 180 & 180 \\
Labor & 587.5 & 587.5 \\
Silicon (10 pipelines) & 62.5 & 62.5 \\
Gaskets to glass cover & 62.5 & 62.5 \\
Spigot & 18.75 & 18.75 \\
Base of distiller & 43.75 & 43.75 \\
& & \\
\hline Total cost & $\mathbf{3 2 0 5}$ & $\mathbf{2 9 5 5}$ \\
\hline
\end{tabular}

The expense of $1 \mathrm{~L}$ of distillate water is found to be about 0.037 and $0.039 \$$ for the stepped and conventional solar stills, separately. To decide the average value of the cost of distillate yield, supposing that $\mathrm{C}$ is the total cost, $\mathrm{F}$ is the fixed cost, $\mathrm{V}$ is the variable cost and $\mathrm{n}$ is the predictable still life time [31] where, $\mathrm{C}=\mathrm{F}+\mathrm{V}$. Supposing variable expense $\mathrm{V}$ equivalents $0.2 \mathrm{~F}$ and the predictable still life time $n=10$ years. From Table 2, the whole cost of the conventional solar still is about $177.3 \$$. To acquire the annual cost for 1 liter, supposing the solar still works 340 days per year, in this way, the total productivity during the conventional solar still life time is $4 * 340 * 10=13600$ liter, accordingly the cost of $1 \mathrm{~L}$ that got from the conventional still $=531.9 / 13600=0.039 \$$. Similarity; from Table 2, the total cost of the stepped solar still is $192.3 \$$. The average daily productivity $4.51 \mathrm{~kg} / \mathrm{m}^{2}$ day, if that the still works 340 days per year, in this way the total productivity during the stepped life time is $4.51 *$ $340 * 10=15334$ liter, so the expense of $1 \mathrm{~L}$ that acquired from stepped system $=576.9 / 15334=0.037$ $\$$.

\section{Conclusion}

Performance of a stepped solar still was investigated using the mathematical modeling. The obtained results indicated that the thermal performance of the stepped system were found to increase with increasing the tray width and height. The daily productivities of the conventional and stepped solar stills are 4 and $4.51\left(\mathrm{~kg} / \mathrm{m}^{2}\right.$ day) with daily efficiencies of 61.48 and $78.33 \%$, individually. The improving in the daily yield and efficiency are acquired as $11.31 \%$ and $21.51 \%$, individually, with the stepped shape basin liner. Comparing the calculated and measured data verified the proposed model to 
be utilized for estimating performance of the stepped solar still. From the optimization of dimensions of the still, it can be concluded that optimum values are; width of the solar still $\left(b_{s}\right)=1 \mathrm{~m}$, water depth $\left(d_{w}\right)=0.02 \mathrm{~m}$, width of $\operatorname{tray}(W)=0.20 \mathrm{~m}$, height of tray $(H)=0.03 \mathrm{~m}$, number of steps $(\mathrm{n})=5$ steps.

\section{Nomenclature}

$A_{g} \quad$ Surface area of the glass cover $\left(\mathrm{m}^{2}\right)$

$A_{b} \quad$ Surface area of the absorber plate $\left(\mathrm{m}^{2}\right)$

$b_{s} \quad$ Width of the solar still $(\mathrm{m})$

$C_{w} \quad$ Specific heat of water $(\mathrm{J} / \mathrm{kg} \mathrm{K})$

$\mathrm{Gr}$ Grasshof number (dimensionless)

$h_{l} \quad$ Total heat transfer coefficient between the basin water and the glass cover $\left(\mathrm{W} / \mathrm{m}^{2} \mathrm{~K}\right)$

$h_{c, b-w}$ Convective heat transfer coefficient between the basin liner and the basin water $\left(\mathrm{W} / \mathrm{m}^{2} \mathrm{~K}\right)$

$h_{c, g-a}$ Convective heat transfer coefficient between the glass cover and the ambient air $\left(\mathrm{W} / \mathrm{m}^{2} \mathrm{~K}\right)$

$h_{c, w-g}$ Convective heat transfer coefficient between the basin water and the glass cover $\left(\mathrm{W} / \mathrm{m}^{2} \mathrm{~K}\right)$

$h_{e, w-g}$ Evaporative heat transfer coefficient between the basin water and the glass cover $\left(\mathrm{W} / \mathrm{m}^{2} \mathrm{~K}\right)$

$h_{r, g-s k y}$ Radiative heat transfer coefficient between the glass cover and the sky $\left(\mathrm{W} / \mathrm{m}^{2} \mathrm{~K}\right)$

$h_{r, w-g} \quad$ Radiative heat transfer coefficient between the basin water and the glass cover $\left(\mathrm{W} / \mathrm{m}^{2} \mathrm{~K}\right)$

$I_{h} \quad$ Solar radiation incident on a horizontal surface $\left(\mathrm{W} / \mathrm{m}^{2}\right)$

$I_{v} \quad$ Solar radiation incident on a vertical surface $\left(\mathrm{W} / \mathrm{m}^{2}\right)$

$K_{w} \quad$ Thermal conductivity of the basin water (W/m K)

$L \quad$ Length of the still (m)

$L_{w} \quad$ Latent heat of vaporization $(\mathrm{J} / \mathrm{kg})$

$m_{w} \quad$ Mass of the basin water $(\mathrm{kg})$

$\Delta T \quad$ Temperature difference between the basin liner and the basin water (k)

$N_{u} \quad$ Nusselt number (dimensionless)

Pr Prantdl number (dimensionless)

$P_{d} \quad$ Daily productivity $\left(\mathrm{kg} / \mathrm{m}^{2}\right.$ day $)$

$P_{g} \quad$ Partial vapor pressure at temperature of the glass cover $\left(\mathrm{N} / \mathrm{m}^{2}\right)$

$P_{h} \quad$ Hourly productivity $\left(\mathrm{kg} / \mathrm{m}^{2} \mathrm{hr}\right)$

$P_{w} \quad$ Partial vapor pressure at temperature of the basin water $\left(\mathrm{N} / \mathrm{m}^{2}\right)$

$T_{a} \quad$ Ambient air temperature $\left({ }^{\circ} \mathrm{C}\right)$

$T_{b} \quad$ Temperature of the basin liner $\left({ }^{\circ} \mathrm{C}\right)$

$T_{g} \quad$ Temperature of the glass cover $\left({ }^{\circ} \mathrm{C}\right)$

$T_{s k y} \quad$ Sky temperature $\left({ }^{\circ} \mathrm{C}\right)$

$T_{w} \quad$ Temperature of the basin water $\left({ }^{\circ} \mathrm{C}\right)$

$T_{w, \max }$ Maximum temperature of the basin water $\left({ }^{\circ} \mathrm{C}\right)$

$\Delta t \quad$ Time interval (s)

$U_{b} \quad$ Bottom loss coefficient $\left(\mathrm{W} / \mathrm{m}^{2} \mathrm{~K}\right)$

$\dot{Q}_{\text {loss }}$ Rate of heat losses from the basin liner to ambient air (watt)

$\dot{Q}_{r, w-g}$ Rate of radiative heat transfers between water and glass cover(watt)

$\dot{Q}_{e, w-g}$ Rate of evaporative heat transfers between water and glass cover (watt)

$\dot{Q}_{c, w-g}$ Rate of convective heat transfers between water and glass cover (watt)

$\dot{Q}_{r, g-s}$ Rate of radiative heat transfers from glass cover to sky(watt)

$\dot{Q}_{c, g-a}$ Rate of convective heat transfers from glass cover to ambient air (watt)

$\dot{Q}_{c, b-w}$ Rate of convective heat transfers from basin liner to basin water(watt)

$V \quad$ Wind speed $(\mathrm{m} / \mathrm{s})$

\section{Greek symbols}

$\alpha_{b} \quad$ Absorptivity of the absorber plate

$\alpha_{g} \quad$ Absorptivity of the glass cover

$\alpha_{w} \quad$ Absorptivity of the still water

$\varepsilon_{g} \quad$ Emissivity of the glass cover

$\eta_{d} \quad$ Daily collection efficiency of the still (\%) 
$\tau_{g} \quad$ Transmissivity of the glass cover

$\tau_{w} \quad$ Transmissivity of the still water

$\sigma \quad$ Stefan-Boltzmann's constant $\left(\mathrm{W} / \mathrm{m}^{2} \mathrm{~K}^{4}\right)$

\section{References}

1- A.S. Nafey, M. Abdelkader, A. Abdelmotalip and A.A. Mabrouk., Parameters affecting solar still productivity, Energy Convers Manage. 41(16) (2000) 1797-1809.

2- M. Feilizadeh, M. Soltanieh, K. Jafarpur, and M.R.K. Estahbanati, A new radiation model for a single-slope solar still,Desalination, 262 (2010) 166-173.

3- A.A. El-Sebaii, Effect of wind speed on some designs of solar stills," Energy Convers. Manage., 41(6) (2000)523-538.

4- N. Khalifa Abdul Jabbar, and M. Ahmad Hamood, On the verification of the effect of water depth on the performance of basin type solar stills, Solar energy, 83 (2009) 1312-1321.

5- A. Azooz and G. G. Younis, Effect of glass inclination angle on solar still performance, Journal of renewable and sustainable energy, 8 (2016) 033702.

6- A. S. Nafey, M. Abdelkader, A. Abdelmotalip, and A. A. Mabrouk, Solar still productivity enhancement, Energy Convers. Manage.42 (2001) 1401-1408.

7- A. A. El-Sebaii, A. A. AL-Gamdi, F. S. AL-Hazmi, and A. S. Faidah, Thermal performance of a single basin solar still with PCM as a storage medium, Applied Energy; 86(7-8) (2009) 11871195 .

8- Mohammad Dashtban, and Farshad Farshchi Tabrizi, Thermal analysis of a weir - type cascade solar still integrated with PCM storage, Desalination; 279 (2011) 415-422.

9- A. F. Muftah, and M. A. Alghoul MA., Factors affecting basin type solar still productivity: A detailed review, Renew. Sustain. Energy Rev., 32 (2014) 430-447.

10- A. E. Kabeel, A. Khalil, Z. M. Omara, and M. M. Younes, Theoretical and experimental parametric study of modified stepped solar still, Desalination, 289 (2012) 12-20.

11- V. Velmurugan, K. J. N. Kumar, T. N. Haq, and K. Srithar, Performance analysis in stepped solar still for effluent desalination, Energy, 34 (2009) 1179-1186.

12- M.R. Abdulhaiy, Transient analysis of a stepped solar still for heating and humidifying greenhouses, Desalination 16(1) (2004) 89-97.

13- A.M. Radhwan, Transient performance of a stepped solar still with built-in latent heat thermal energy storage, Desalination 171 (2004) 61-76.

14- L. Jim, M. Gil, W. Marry and Y. Lily, More other homes and garbage (San Francisco, California Sierra Club Books), P.304(1981).

15- M. Dashtan and F.F. Tabrizi, Thermal analysis of a weir-type cascade solar still integrated with PCM storage, Desalination 279 (2011) 415-22.

16- Z.M. Omara, Performance of finned and corrugate absorber solar stills under Egyptian conditions, Desalination 277 (2011) 281-7. 
17- A. ALaudeen, K. Johnson, P. Ganasundar, A.S. Abuthahir and K. Srithar, Study on stepped type basin in a solar stil, J.King.Saud.Univ.Eng.Sci 26(2) (2012) 176-183.

18- S.W. Sharshir, M.A. Eltawil and A.M. Algazzar, performance enhancement of stepped double slope solar still by using nanoparticles and linen wicks: Energy, Exergy and economic analysis, Applied Thermal Engineering 174 (2020) 115278.

19- A. S. Abdullah, Improving the performance of stepped solar still, Desalination, 319 (2013) 6065.

20- S. Mohammed Shadi. Abujazar, S. Fatihah, and A. E. Kabeel, Seawater desalination using inclined stepped solar still with copper trays in a wet tropical climate, Desalination, 423 (2017) 141-148.

21- Mehrnaz Naroei, Faramarz Sarhaddi, and Fatemeh Sobhnamayan, Efficiency of a photovoltaic thermal stepped solar still: Experimental and numerical analysis, Desalination, 441 (2018) 87-95.

22- A.J.G. Beik, M.R. Assari and H.B. Tabrizi, Passive and active performance of a multi-sidestepped square pyramid solar still; experimental and modeling, Journal of Energy Storage 32 (2020) 101832.

23- A.N. Shamroukh and S. Ookawara. Evaluation of Transparent Acrylic Stepped Solar Still Equipped with Internal and External Reflectors and Copper Fins, TSEP (2020) 100518.

24- J. A. Duffie, and W. A. Beckman, Solar engineering of thermal processes, 4th ed, John Wiley $\&$ Sons, New York (2013).

25- I. Altarawneh, S. Rawadieh, M. Batiha, L. Al-Makhadmeh, S. Alrowwad, and M. Tarawneh, Experimental and numerical performance analysis and optimization of single slope, double slope and pyramidal shaped solar stills, Desalination, 423 (2017) 124-134.

26- G. N. Tiwari, A.Tiwari, and Shyam, Handbook of Solar Energy: Theory, Analysis and Applications, Springer, Singapore (2016).

27- V. B. Sharma, and S. C. Mullick, Estimation of heat transfer coefficients, the upward heat flow and evaporation in a solar still, Journal of solar energy engineering, 113(1) (1991) 36-41.

28- A. Alaudeen, K. Johnson, P. Ganasundar, A. S. Abuthahir, and K. Srithar, Study on stepped type basin in a solar still, J. King. Saud. Univ. Eng. Sci. 26(2) (2012) 176-183.

29- A. F. Muftah, K. Sopian, and M. A. Alghoul, 2018, Performance of basin type stepped solar still enhanced with superior design concepts, Desalination, 435 (2018) 198-209.

30- Z. M. Omara, A. E. Kabeel, and M. M. Younes, Enhancing the stepped solar still performance using internal reflectors, Desalination, 314 (2018) 67-72x.

31- A. A. El-Sebaii, and M. El-Naggar, Year round performance and cost analysis of a finned single basin solar still, Applied thermal engineering, 110 (2017) 787-794. 